\title{
Apathy and depressive symptoms in older people and incident myocardial infarction, stroke, and mortality: a systematic review and meta-analysis of individual participant data [Erratum]
}

Eurelings LSM, van Dalen JW, ter Riet G, et al. Clin Epidemiol. 2018;10:363-379.
Page 363, affiliations section, "On behalf of the ICARA Study Group" should instead read "and the ICARA study group".

\section{Publish your work in this journal}

Clinical Epidemiology is an international, peer-reviewed, open access, online journal focusing on disease and drug epidemiology, identification of risk factors and screening procedures to develop optimal preventative initiatives and programs. Specific topics include: diagnosis, prognosis, treatment, screening, prevention, risk factor modification, systematic reviews, risk \& safety of medical interventions, epidemiology \& biostatistical methods, and evaluation of guidelines, translational medicine, health policies \& economic evaluations. The manuscript management system is completely online and includes a very quick and fair peer-review system, which is all easy to use. 